\title{
Foot Type Classification of Korean Male Farmers for Ergonomic Work Shoes Design
}

\author{
Dohee Kim $^{1}$, Kyoung Suk Hwang ${ }^{2}$, Kyung Suk Lee ${ }^{3}$ \\ ${ }^{1,3}$ Agricultural Safety Engineering Division, Rural Development Administration, Suwon, 441-707 \\ ${ }^{2}$ Textile and Consumer Goods Examination Division, Korean Intellectual Property Office, Daejeon, 302-701
}

\begin{abstract}
Objective: The aim of this study is to identify foot shapes of Korean male farmers by classifying their foot types using 3D scan data and analyzing the characteristics of each type. Background: The increasing demands for anthropometric information for the design of machinery and personal protective equipment to prevent occupational injuries has necessitated an understanding of the anthropometric differences to be found among occupations. Static stooped posture and squatting posture are so common in Korean farmers that anthropometric deformation in foot especially seems to occur easily. Method: 366 Korean male farmers volunteered for this study from 16 different farming villages nationwide from 2009 to 2011. Subjects were categorized into 4 age groups from $40 \mathrm{~s}$ to $70 \mathrm{~s}$. Their right feet were measured by using 3D foot scanner, the anthropometric dimensions were composed of 40 items. Results: The 8 major factors affecting the foot shapes were extracted. From these factors the foot shape of Korean male farmers was classified into 3 Foot types. Foot type 1 showed severe deformation in toe 1, type 2 had a narrow shape and type 3 had a wider width for its length. Conclusion: There were some differences in foot shape and types between farmers and the public. The most characteristic foot type in Korean male farmers was type 3. Application: The results of identifying foot shapes of Korean male farmers might provide the useful information for designing ergonomic farm work shoes.
\end{abstract}

Keywords: Farmers, Ergonomic work shoes, Foot type classification, Anthropometric information, 3D foot scan

\section{Introduction}

체형은 유전적 요인 뿐 아니라 반복된 작업 및 자세 등 생활환경적 요인에도 영향을 받는다. 특히 해부학적으로 하 지의 말단부에 위치하면서 지면으로부터 인체에 가해지는 충격을 일차적으로 흡수하는 발은 후천적 영향에 의하여 쉽 게 변형될 수 있는 기관이다(Sparger, 1970). 이러한 발 은 인체의 직립 보행과 균형 유지에 중요한 역할을 담당하 고 자세의 기초가 되므로 인간의 건강과 밀접한 관련이 있
다(Song, 1986).

이처럼 중요한 발에 관해 다양한 연구들이 진행되었는데, 발의 형태 분류 및 특성에 관한 연구(Moon, 1994; Seong, 1999; Seong et al., 2006; Kouchi, 1998; Ashizawa et al., 1997; Morimoto and Okada, 1985), 편안한 신발 설계를 위한 연구(Wunderich and Cavanagh 2001; Leem et al., 2007), 변형된 발의 기능 및 재활에 관한 연구(Kim, 1996; Lee and Choi, 2011) 등으로 분류할 수 있다. 특히 급속히 진행되는 고령화로 인한 노인 인구의 증가 및 이들의 건강에 대한 관심으로 노인층의 발 형태 및 신발 개발에 관한 다수

Corresponding Author: Kyung Suk Lee. Agricultural Safety Engineering Division, Rural Development Administration, Suwon, $441-707$.

Phone: +82-31-290-1937, E-mail: leeks81@korea.kr

Copyright@2012 by Ergonomics Society of Korea(pISSN:1229-1684 eISSN:2093-8462). All right reserved.

(c) This is an open-access article distributed under the terms of the Creative Commons Attribution Non-Commercial License(http://creativecommons.org/licenses/by-nc/3.0/), which permits unrestricted non-commercial use, distribution, and reproduction in any medium, provided the original work is properly cited. http://www.esk.or.kr 
의 연구들이 진행되었는데, 일반적으로 노인의 발은 오랜 시 간 동안의 신발 착용 및 습관, 질병 등에 의해 변형된 경우 가 많아, 다른 연령층과는 차이가 있었다(Jung and Lee, 2001). 한편 운동선수와 일반인의 발 형태를 비교한 Kouchi and Mochimaru(2003), Morimoto and Okada(1985) 등의 연구에서는 운동선수가 일반인보다 발이 더 두껍고 발의 아 치 (arch) 가 낮다는 결과가 보고되었으며, 연구자들은 이러 한 차이가 발에 가해지는 물리적 스트레스에 기인한다고 분 석하였다. 그런데 이러한 연구의 대부분은 도시 거주자나 운 동선수 등 일부 특수 집단을 대상으로 하고 있으며, 농업인 이 대상으로 포함된 연구는 거의 없다.

우리나라 농촌은 고령 인구의 비율이 도시에 비해 매우 높 고(Statistics Korea, 2010), 농작업 시 장시간 쪼그려 앉 거나 구부린 상태에서의 반복된 작업이 많아 비농업인과의 체형의 차이가 관찰된 바 있는데(Kim et al., 2011a), 이러 한 농업인과 비농업 인간의 체형의 차이는 특히 외부의 물 리적 스트레스에 의해 쉽게 손상될 수 있는 약한 구조로 이 루어진 기관(Sparger, 1970)인 발 부위에서 확연히 나타날 것으로 사료된다. Kim et al. (2011b) 의 연구에서도 농업인이 비농업인보다 발둘레와 너비가 크게 나타나 발 형태의 차이 가 일부 확인된 바 있다.

또한 현재 신발 제작에 사용되는 국내외 치수체계(ISO, 1991; JIS, 1998; KS, 2001, 2007)는 단지 발길이와 발둘 레, 발너비 등 단순 치수 항목으로 구성되어 입체적인 발 형 태를 반영하기에는 무리가 있기 때문에 신발 착용 시 불편함 이나 통증을 유발하는 원인으로 작용할 수 있다. Chun and Choi (2000), Han(2005) 등의 도시 거주 여성을 대상으로 신발 착용에 대한 여러 조사연구 결과에서 대다수의 응답 자들은 신발 착용에 대한 불편을 호소하고 있었다. 일반인 (non-farmers)에 비해 발너비가 넓은 농업인(Hojo and Nakashima, 1985; Kim et al., 2011)에게는 이러한 치수체 계에서 제작된 신발을 착용하는 것이 더욱 불편할 수 있을 것으로 보이며, 실제 농작업화 착용 실태를 조사한 Lee and Choi(1996)의 연구에서 신발의 맞음새에 대한 불편감을 호 소한 사례가 많았던 결과도 같은 맥락에서 이해할 수 있을 것이다. 이렇게 잘 맞지 않는 신발은 발의 문제 및 변형을 야기할 수 있으며, 이러한 발의 변형은 또다시 신발 맞음새 를 문제를 악화시킬 수 있어(Frey et al., 1993; Frey, 2000; Burns et al., 2002, Menz and Morris, 2005) 심각한 문제 라 할 수 있다.

이에 본 연구에서는 한국 농업인 발 형상을 측정, 수집한 자료를 분석하여 발 유형을 분류하고 유형별 특성 및 분포 를 제시함으로써 농업인에게 적합한 인간공학적 작업화 설 계를 위한 기초자료를 제공하는 데에 그 목적이 있으며, 이 를 통해 농업인의 농작업 부담을 감소시키는 데에 일조하고
자 한다. 본 보에서는 전체 수집한 자료 중 남성 농업인의 발 형태를 분석하였다.

\section{Method}

\subsection{Subjects}

2009년 4월부터 2011년 7월까지 전국 8개도, 16 개 농촌 마을(강원 고성, 경남 거창, 경북 영주, 전남 강진, 전북 고 창, 충남 예산, 충북 진천 등)에서 5년 이상 지속적으로 농 업에 종사해온 40세 이상 80세 미만의 특별한 발 관련 질 환이 없는 농업인을 대상으로 측정을 실시하였다.

연구에 참여한 남성 농업인은 총 366 명이며, 연령별 분 포는 Table 1 에 제시하였다.

Table 1. The age distribution of subjects

(frequency $(\%)$ )

\begin{tabular}{c|c|c|c|c|c}
\hline Age(yr) & $40 \sim 49$ & $50 \sim 59$ & $60 \sim 69$ & Over 70 & Total \\
\hline Subjects(\%) & 44 & 90 & 127 & 105 & 366 \\
& $(12.0)$ & $(24.6)$ & $(34.7)$ & $(28.7)$ & $(100)$ \\
\hline
\end{tabular}

\subsection{Measurement items and procedure}

본 연구에서는 농업인의 발 치수 측정을 위해 3 차원 측 정법을 사용하였고 발측정 장비와 측정 기준점, 측정 방법 및 치수 추출 방법은 제 5 차 한국인 인체치수조사사업 보고 서(KATS, 2004)에 기술된 것과 동일하다.

측정을 위해 먼저 피측정자의 발에 치수 추출을 위한 기 준점 13 개를 표시한 뒤 3 차원 발스캐너(IFU-H-O1, IWare Laboratory Co., Ltd, Japan)를 이용하여 선 자세에 서 농업인의 오른쪽 발을 스캐닝한 후, 스캐닝한 형상을 저 장하였다. 저장된 발 형상으로부터 발 치수를 추출할 때에는 Foot Dimension 프로그램을 활용하였고, 발에 표시된 기준 점 13 개와 프로그램 상에서 설정하는 기준점 11 개, 총 24 개 의 기준점 (Table 2, Figure 1)을 이용하여 40개의 발 치수 항목을 추출하였다. 자세한 발 치수 항목 및 그 측정 방법은 Fgure 2와 Table 3에 제시하였다.

\subsection{Data analysis}

자료의 분석에는 SPSS 14.0 Statistical Package Program 을 이용하였고, 추출된 치수 데이터는 항목별, 연령별 평균 과 표준편차에 의하여 평균으로부터 $\pm 3 \sigma$ 이상 벗어난 값 
Table 2. Foot landmarks

\begin{tabular}{|c|c|c|}
\hline No. & Term & Description \\
\hline 1 & Metatarsophalangeal I & $\begin{array}{l}\text { The most prominent point on } \\
\text { the inner side of the foot }\end{array}$ \\
\hline 2 & Metatarsophalangeal V & $\begin{array}{l}\text { The most prominent point on } \\
\text { the outer side of the foot }\end{array}$ \\
\hline 3 & Toe 1 joint & $\begin{array}{l}\text { The highest point of the } 1^{\text {st }} \text { toe at } \\
\text { the interphalangeal joint }\end{array}$ \\
\hline 4 & Toe 5 joint & $\begin{array}{l}\text { The highest point of the } 5^{\text {th }} \text { toe joint } \\
\text { at the distal interphalangeal joint }\end{array}$ \\
\hline 5 & $\begin{array}{l}\text { Sesamoid bone point } \\
\text { (toe 1) }\end{array}$ & $\begin{array}{l}\text { The highest point of the } \\
\text { medial sesamoid bone }\end{array}$ \\
\hline 6 & Instep point & $\begin{array}{l}\text { The highest point of the } \\
\text { intermediate cuneiform }\end{array}$ \\
\hline 7 & Ankle point-right & $\begin{array}{l}\text { The auxiliary ankle point moved } \\
\text { to the right }\end{array}$ \\
\hline 8 & Navicular & $\begin{array}{l}\text { The highest point of the } \\
\text { navicular }\end{array}$ \\
\hline 9 & Lateral malleolus & $\begin{array}{l}\text { The most lateral point of the } \\
\text { lateral malleolus }\end{array}$ \\
\hline 10 & Medial malleolus & $\begin{array}{l}\text { The most medial point of the } \\
\text { medial malleolus }\end{array}$ \\
\hline 11 & Sphyrion fibulare & $\begin{array}{l}\text { The most distal point of the } \\
\text { lateral malleolus }\end{array}$ \\
\hline 12 & Sphyrion & $\begin{array}{l}\text { The most distal point of } \\
\text { medial malleolus }\end{array}$ \\
\hline 13 & $\begin{array}{l}\text { Upper point of the } \\
\text { heel-medial }\end{array}$ & $\begin{array}{l}\text { The auxiliary upper point of the } \\
\text { heel moved to the medial }\end{array}$ \\
\hline 14 & Pternion & $\begin{array}{l}\text { The most backward and prominent } \\
\text { point of the heel }\end{array}$ \\
\hline 15 & $\begin{array}{l}\text { Landing point } \\
\text { of the heel }\end{array}$ & $\begin{array}{l}\text { The point where the heel } \\
\text { and the floor }\end{array}$ \\
\hline 16 & Toe 1 end point & The end point of $1^{\text {st }}$ toe \\
\hline 17 & Toe 2 end point & The end point of $2^{\text {nd }}$ toe \\
\hline 18 & Toe 5 end point & The end point of $5^{\text {th }}$ toe \\
\hline 19 & Center line & Line from pternion to toe 2 end point \\
\hline 20 & Ball line & $\begin{array}{l}\text { Line from the metatarsophalangeal I } \\
\text { to the metatarsophalangeal } \mathrm{V}\end{array}$ \\
\hline 21 & Ball center line & $\begin{array}{l}\text { Line from the pternion to the } \\
\text { mid-point of ball Line }\end{array}$ \\
\hline 22 & Ball center point & $\begin{array}{l}\text { The intersection of the center line } \\
\text { and the ball line }\end{array}$ \\
\hline 23 & Ankle point & $\begin{array}{l}\text { The mid-point of the line that } \\
\text { connect between the lateral and } \\
\text { medial malleolus }\end{array}$ \\
\hline 24 & $\begin{array}{l}\text { Upper point } \\
\text { of the heel }\end{array}$ & $\begin{array}{l}\text { The most upper-hollow point } \\
\text { of the heel }\end{array}$ \\
\hline
\end{tabular}

* 1 13: These points require attaching landmarks

*14 24: These points are generated in the software program

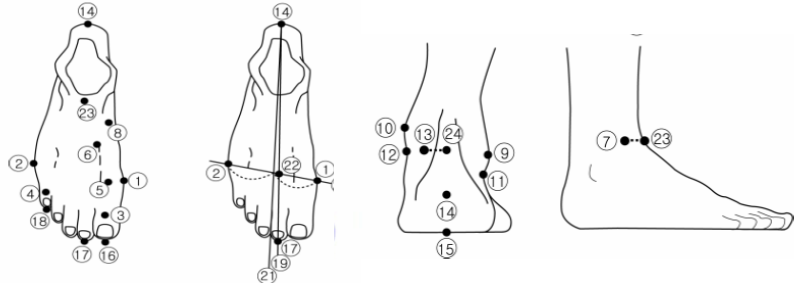

Figure 1. Foot landmarks
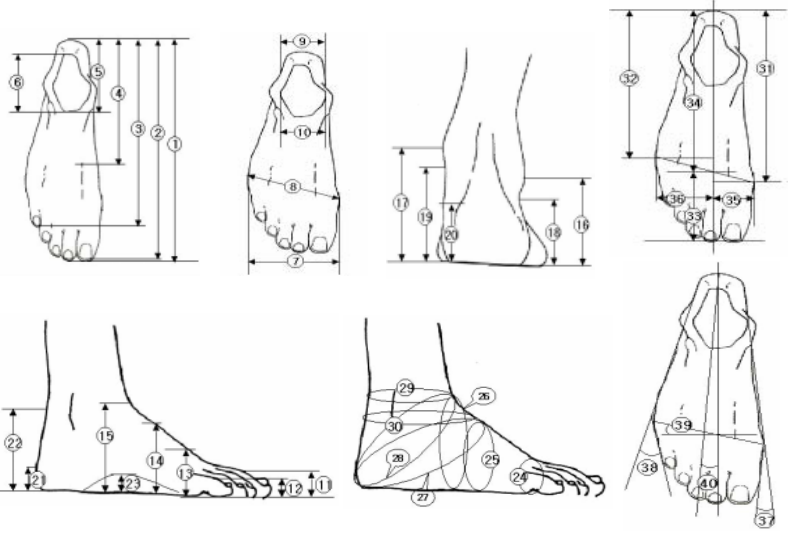

Figure 2. Foot dimensions

들을 일단 이상 데이터로 분류, 원본과 대조하여 수정 및 삭 제하였다.

총 40 개의 발측정 항목 중 각도 관련 4 항목을 제외한 36 항목은 크기로 인한 영향력을 최소화하기 위하여 '발길 이'로 나눈 지수치를 사용하였다.

분석 방법으로는 첫째, 축약된 소수의 요인으로 남성 농업 인 발 형태를 나타내기 위해 40개 치수 항목에 대한 탐색적 요인분석(exploratory factor analysis)을 실시하였다. 적절 한 요인수는 고유값(Eigen value)을 기준으로 결정하였고, 명확한 요인구조를 파악하기 위해 고유값 1.0 이상을 나타 내는 주성분에 대하여 Varimax 직교회전을 실시하였다. 둘 째, 남성 농업인 발 형태를 유형별로 분류하기 위해 요인분 석에서 추출된 항목들의 요인점수를 독립변수로 하여 군집분 석을 실시하였다. 먼저, 적절한 군집의 개수를 검토하기 위 해 덴드로그램(Dendrogram)을 이용하였고 제곱 Euclidean 거리 척도를 사용하여 군집간 거리를 산출하였다. 그리고 군 집의 수를 임의로 2 6개까지 지정하여 군집간 특성 및 차 이를 분석하였고, 최종적으로 발의 형태적 특징이 가장 잘 나타나며, 군집간 차가 뚜렷한 3 개의 군집으로 결정하였다. 셋째, 각 군집의 특성을 파악하기 위해 군집별 요인점수 및 측정 항목을 분산분석 및 사후검정을 통해 비교분석 하였다. 마지막으로 연령층별 군집의 분포를 비교하여 연령에 따른 
Table 3. Foot dimensions

\begin{tabular}{|c|c|c|c|}
\hline No. & Dimension & Reference points & Description \\
\hline 1 & Foot length & $\begin{array}{l}\text { Pternion, Acropodion } \\
\text { (the tip of the toe } \# 1 \text { or the toe } \# 2 \text { ) }\end{array}$ & $\begin{array}{l}\text { The horizontal distance between the pternion and the tip the } \\
\text { longest toe of the foot(Acropodion) }\end{array}$ \\
\hline 2 & Heel-to-Toe \#1 length & Pternion, toe 1 end point & The horizontal distance between the pternion and the toe 1 end point \\
\hline 3 & Heel-to-Toe \#5 length & Pternion, toe 5 end point & The horizontal distance between the pternion and the toe 5 end point \\
\hline 4 & Heel-to-Instep length & Pternion, instep point & The horizontal distance between the pternion and the instep point \\
\hline 5 & Heel-to-Ankle length & Pternion, ankle point & The horizontal distance between the pternion and the ankle point \\
\hline 6 & Ankle thickness & Ankle point & $\begin{array}{c}\text { The distance measured perpendicular to ankle width section at the } \\
\text { ankle point }\end{array}$ \\
\hline 7 & Foot width & $\begin{array}{l}\text { Metatarsophalangeal I, } \\
\text { Metatarsophalangeal V }\end{array}$ & $\begin{array}{l}\text { The horizontal distance between the metatarsophalangeal I } \\
\text { and the metatarsophalangeal V }\end{array}$ \\
\hline 8 & Ball distance & $\begin{array}{l}\text { Metatarsophalangeal I, } \\
\text { Metatarsophalangeal V }\end{array}$ & $\begin{array}{c}\text { The distance of the straight line between the metatarsophalangeal I } \\
\text { and the metatarsophalangeal V }\end{array}$ \\
\hline 9 & Heel width & Pternion & $\begin{array}{l}\text { The horizontal distance between the outer edges of the foot at } 16 \% \\
\text { of foot length from the pternion, perpendicular to the foot length }\end{array}$ \\
\hline 10 & Ankle width & Pternion & The horizontal width of the ankle at the ankle point \\
\hline 11 & Toe 1 height & Toe 1 joint & The vertical distance between the toe 1 joint and the floor \\
\hline 12 & Toe 5 height & Toe 5 joint & The vertical distance between the toe 5 joint and the floor \\
\hline 13 & Ball height & Sesamoid bone point(toe 1$)$ & The vertical distance between the Sesamoid bone point and the floor \\
\hline 14 & Instep height & Instep point & The vertical distance between the instep point and the floor \\
\hline 15 & Ankle height & Ankle point-right & The vertical distance between the ankle point-right and the floor \\
\hline 16 & Lateral malleolus height & Lateral malleolus & The vertical distance between the floor and the lateral malleolus \\
\hline 17 & Medial malleolus height & Medial, alleolus & The vertical distance between the floor and the medial malleolus \\
\hline 18 & Sphyrion fibulare height & Sphyrion fibulare & The vertical distance between the floor and the sphyrion fibulare \\
\hline 19 & Sphyrion height & Sphyrion & The vertical distance between the floor and the sphyrion \\
\hline 20 & Navicular height & Navicular & The vertical distance between the navicular tuberosity and the floor \\
\hline 21 & Heel height & Pternion & The vertical distance between the floor and the pternion \\
\hline 22 & $\begin{array}{l}\text { Height of upper point } \\
\text { of heel point }\end{array}$ & Upper point of the heel-medial & $\begin{array}{l}\text { The vertical distance between the floor and the upper point } \\
\text { of the heel-medial }\end{array}$ \\
\hline 23 & Arch height & Sesamoid bone point(toe $\# 1)$ & $\begin{array}{l}\text { The maximum arch height at the vertical cross section area passing } \\
\text { through sesamoid bone point. The cross section area is parallel } \\
\text { with the center line }\end{array}$ \\
\hline 24 & Ball circumference & $\begin{array}{l}\text { Metatarsophalangeal I, } \\
\text { metatarsophalangeal V }\end{array}$ & $\begin{array}{l}\text { The circumference of the vertical cross section passing across the } \\
\text { metatarsophalangeal I and the metatarsophalangeal V }\end{array}$ \\
\hline 25 & Instep circumference & Instep point & The circumference of the vertical cross section at the instep point \\
\hline 26 & $\begin{array}{l}\text { Perpendicular ankle } \\
\text { circumference }\end{array}$ & Ankle point & The circumference of the vertical cross section at the ankle point \\
\hline 27 & $\begin{array}{l}\text { Heel-to-Instep } \\
\text { circumference }\end{array}$ & $\begin{array}{l}\text { Landing point of the heel, } \\
\text { instep point }\end{array}$ & $\begin{array}{l}\text { The circumference of the vertical cross section passing across the } \\
\text { landing point of the heel and the instep point }\end{array}$ \\
\hline 28 & $\begin{array}{l}\text { Heel-to-Ankle } \\
\text { circumference }\end{array}$ & $\begin{array}{l}\text { Landing point of the heel, } \\
\text { ankle point }\end{array}$ & $\begin{array}{l}\text { The circumference of the vertical cross section passing across the } \\
\text { landing point of the heel and the ankle point }\end{array}$ \\
\hline 29 & $\begin{array}{l}\text { Horizontal ankle } \\
\text { circumference }\end{array}$ & Ankle point & The circumference of the horizontal cross section at the ankle point \\
\hline 30 & Sphyrion circumference & Sphyrion & The circumference of the horizontal cross section at the sphyrion \\
\hline 31 & Heel-to-Tibiale length & Pternion, metatarsophalangeal I & $\begin{array}{l}\text { The horizontal distance between the pternion and the } \\
\text { metatarsophalangeal I }\end{array}$ \\
\hline
\end{tabular}


Table 3. Foot dimensions (Continued)

\begin{tabular}{|c|c|c|c|}
\hline No. & Dimension & Reference points & Description \\
\hline 32 & Heel-to-Fibulare length & pternion, metatarsophalangeal V & $\begin{array}{l}\text { The horizontal distance between the pternion and the } \\
\text { metatarsophalangeal V }\end{array}$ \\
\hline 33 & Ball Center-to-Toe 2 length & Ball center point, toe 2 end point & $\begin{array}{l}\text { The horizontal distance between the ball center point and the } \\
\text { toe } 2 \text { end point }\end{array}$ \\
\hline 34 & Ball Center-to-Heel length & Ball center point, pternion & The horizontal distance between the ball center point and the pternion \\
\hline 35 & Medial ball width & Center line, metatarsophalangeal I & $\begin{array}{l}\text { The perpendicular distance from the metatarsophalangeal I to the } \\
\text { center line on the ball line }\end{array}$ \\
\hline 36 & Lateral ball width & Center line, metatarsophalangeal $\mathrm{V}$ & $\begin{array}{l}\text { The perpendicular distance from the metatarsophalangeal V } \\
\text { to the center line on the ball line }\end{array}$ \\
\hline 37 & Toe 1 angle & Metatarsophalangeal I & $\begin{array}{l}\text { The acute angle between the extended line from the medial heel width } \\
\text { point to the metatarsophalangeal I and the line between the } \\
\text { metatarsophalangeal I and the outer edge of the toe } 1 \text { joint }\end{array}$ \\
\hline 38 & Toe 5 angle & Pternion, metatarsophalangeal V & $\begin{array}{l}\text { The acute angle between the extended line from the pternion to the } \\
\text { metatarsophalangeal } V \text { and the line between the metatarsophalangeal } \mathrm{V} \\
\text { and the outer edge of the toe } 5 \text { joint. }\end{array}$ \\
\hline 39 & Ball line angle & Center line, ball line & $\begin{array}{l}\text { The acute angle between the ball line and the vertical line } \\
\text { to the center line }\end{array}$ \\
\hline 40 & Center line angle & Center line, ball center line & The acute angle between the ball center line and the center line \\
\hline
\end{tabular}

차이를 분석하였다.

\section{Results}

\subsection{Extract construction factors of foot shapes}

남성 농업인의 발 측정치에 대한 최종 요인분석 결과 길 이 8항목, 너비 4항목, 높이 6항목, 둘레 5항목, 각도 3항 목, 두께 1 항목 등 총 27 개의 항목을 사용, 8 개의 요인이 추 출되었고, 발 형태에 대한 총 $82.5 \%$ 의 설명력을 나타냈다 (Table 4).

요인 1은 볼거리, 발둘레 등 발 앞쪽 부위의 형태와 관련 된 요인으로 고유치는 4.569 이었고, $16.92 \%$ 의 기여율을 나 타냈다. 요인 2는 안쪽복사높이 (Medial Malleolus Height), 가쪽복사높이 (Lateral Malleolus Height) 등 복사높이 요 인으로 $13.75 \%$ 의 설명력을 나타냈다. 요인 3은 발중심선 (Center Line)을 기준으로 엄지 발가락과 볼중심점(Ball Center Point)의 위치관계를 나타내는 요인으로 볼 내측의 형태 및 엄지의 변형 정도, 무지외반증과 관련이 있으며 $11.75 \%$ 의 기여율을 보였다. 요인 4 는 발중심점상측길이 (Ball Center to Toe 2 Length) 와 발중심점하측길이 (Ball Center to Heel Length) 의 비율과 관련된 요인으로 9.55\% 의 설명력을 나타냈다. 요인 5 는 발꿈치에서 발등의 직선거 리 및 둘레, 발등높이와 관련된 요인으로 발꿈치 발등 사이
의 형태를 나타내며 $9.37 \%$ 의 설명력을, 요인 6 은 볼 가측 의 형태 및 새끼 발가락의 위치와 관련된 요인으로 $8.80 \%$ 의 설명력을, 요인 7 은 발목의 굵기와 관련된 요인으로 분 석되며 $8.31 \%$ 의 설명력을 나타냈다. 마지막으로 요인 8 은 엄지 발가락 길이 항목만으로 이루어지는데, 본 연구에서는 발의 형태에 관한 요인 및 군집분석에서 각도를 제외한 모 든 항목을 발길이에 대한 지수 항목으로 변환하여 사용하였 으므로 요인 8은 엄지 발가락과 둘째 발가락의 상대적 길이 의 차로 해석할 수 있을 것이다. 이 요인이 설명하는 발의 특성은 전족부 형태 분류 방법 중 발가락 길이에 따라 발을 엄지 발가락이 긴 이집트인 형(Egyptian foot), 엄지와 둘 째 발가락의 길이가 비슷한 정돈된 형(Squared foot), 둘째 발가락이 엄지 발가락보다 긴 그리스인 형 (Greek foot)으 로 분류하는 Viladot(1973)의 발가락 형 분류 방법(digital formula) 과 유사한 것으로 보인다.

발의 형태에 관한 여러 선행연구에서 길이, 둘레, 너비 등 단순 크기 항목이 주요 요인으로 추출된 것에 비해 본 연구 에서는 지수 항목을 분석에 활용함으로써 발의 입체적 형상 에 대한 상대적 형태 및 위치가 주된 요인으로 추출되어 실 제 농작업화 제작 시 보다 실질적인 자료로 활용될 수 있을 것으로 사료된다.

\subsection{Classification of foot types}

남성 농업인의 발 형태를 몇 개의 동질적인 군집으로 분류 
Table 4. The result of factor analysis

\begin{tabular}{|c|c|c|}
\hline $\begin{array}{c}\text { Factor } \\
\text { eigen value } \\
\text { (\% of variance) }\end{array}$ & Foot dimensions & $\begin{array}{l}\text { Factor } \\
\text { loading }\end{array}$ \\
\hline \multirow{5}{*}{$\begin{array}{c}\text { Factor } 1 \\
4.569 \\
(16.92 \%)\end{array}$} & 8.Ball distance & .933 \\
\hline & 7.Foot width & .927 \\
\hline & 24.Ball circumference & .866 \\
\hline & 25.Instep circumference & .805 \\
\hline & 26.Perpendicular ankle circumference & .772 \\
\hline \multirow{5}{*}{$\begin{array}{c}\text { Factor } 2 \\
3.712 \\
(13.75 \%)\end{array}$} & 19.Sphyrion height & .898 \\
\hline & 17.Medial malleolus height & .889 \\
\hline & 22.Height of upper point of heel point & .761 \\
\hline & 15.Ankle height & .734 \\
\hline & 16.Lateral malleolus height & .709 \\
\hline \multirow{4}{*}{$\begin{array}{c}\text { Factor } 3 \\
3.173 \\
(11.75 \%)\end{array}$} & 40.Center line angle & .936 \\
\hline & 35.Medial ball width & -.882 \\
\hline & 37.Toe 1 angle & -.808 \\
\hline & 36.Lateral ball width & .758 \\
\hline \multirow{3}{*}{$\begin{array}{l}\text { Factor } 4 \\
2.578 \\
(9.55 \%)\end{array}$} & 31.Heel to tibiale length & .941 \\
\hline & 34. Ball center to heel length & .860 \\
\hline & 33. Ball center to toe 2 length & -.728 \\
\hline \multirow{3}{*}{$\begin{array}{l}\text { Factor } 5 \\
2.531 \\
(9.37 \%)\end{array}$} & 4.Heel to instep length & .976 \\
\hline & 27.Heel to instep circumference & .920 \\
\hline & 14.Instep height & -.800 \\
\hline \multirow{3}{*}{$\begin{array}{l}\text { Factor } 6 \\
2.376 \\
(8.80 \%)\end{array}$} & 39.Ball line angle & -.910 \\
\hline & 32.Heel to fibulare length & .839 \\
\hline & 3.Heel to toe 5 length & .666 \\
\hline \multirow{3}{*}{$\begin{array}{l}\text { Factor } 7 \\
2.244 \\
(8.31 \%)\end{array}$} & 6.Ankle thickness & .895 \\
\hline & 5.Heel to ankle length & .850 \\
\hline & 29.Horizontal ankle circumference & .690 \\
\hline $\begin{array}{l}\text { Factor } 8 \\
1.214 \\
(4.50 \%)\end{array}$ & 2.Heel to toe 1 length & .920 \\
\hline \multicolumn{2}{|r|}{ Cumulative \% (82.5\%) } & \\
\hline
\end{tabular}

하기 위해 요인분석에서 추출된 8개의 요인점수를 독립변수 로 하여 군집분석을 실시하였다. 군집수를 2 6개까지로 분 류하여 검토해본 결과, 군집간 발의 형태적 특징이 가장 잘 나타내며 군집간 구분이 뚜렷한 3 개 유형으로 분류하였다.

농업인의 군집별 분포와 8개 요인에 대한 군집간 차이 및 각 군집별 발 형태의 특징을 살펴보기 위해 군집별로 요인점 수에 대한 분산분석 및 사후검정 결과를 Table 5 에 제시하 였다. 8개의 요인 모두에 대해 군집간 유의한 차이가 있었는 데, 군집 1 은 엄지의 변형 정도를 나타내는 요인 3 과 발목의
굵기를 나타내는 요인 7에서 다른 두 군집과 특히 큰 차이 를 보였다. 군집 2 는 발 앞부분의 부피를 설명하는 요인 1 과 엄지 발가락과 둘째 발가락의 길이 비를 나타내는 요인 8 에서, 군집 3 은 발꿈치 발등의 길이를 설명하는 요인 5 와 발목의 굵기를 나타내는 요인 7 에서 다른 군집들과 현저한 차이를 보였다.

Table 5. The differences of factor scores among the clusters

\begin{tabular}{c|c|c|c|c}
\hline Factor & $\begin{array}{c}\text { Cluster } \\
(\mathrm{n}=119)\end{array}$ & $\begin{array}{c}\text { Cluster 2 } \\
(\mathrm{n}=81)\end{array}$ & $\begin{array}{c}\text { Cluster 3 } \\
(\mathrm{n}=166)\end{array}$ & $F$-value \\
\hline Factor 1 & $.07327^{\mathrm{b}}$ & $-.67632^{\mathrm{a}}$ & $.27749^{\mathrm{b}}$ & $29.124^{* * *}$ \\
\hline Factor 2 & $-.18696^{\mathrm{a}}$ & $.39150^{\mathrm{b}}$ & $-.05701^{\mathrm{a}}$ & $8.929^{* * *}$ \\
\hline Factor 3 & $-.74283^{\mathrm{a}}$ & $.09784^{\mathrm{b}}$ & $.48477^{\mathrm{c}}$ & $73.739^{* * *}$ \\
\hline Factor 4 & $.22090^{\mathrm{b}}$ & $-.31524^{\mathrm{a}}$ & $-.00453^{\mathrm{b}}$ & $7.164^{* *}$ \\
\hline Factor 5 & $-.22812^{\mathrm{a}}$ & $-.22426^{\mathrm{a}}$ & $.27296^{\mathrm{b}}$ & $11.999^{* * *}$ \\
\hline Factor 6 & $-.37287^{\mathrm{a}}$ & $.10445^{\mathrm{b}}$ & $.21633^{\mathrm{b}}$ & $13.459^{* * *}$ \\
\hline Factor 7 & $.64539^{\mathrm{c}}$ & $-.13403^{\mathrm{b}}$ & $-.39726^{\mathrm{a}}$ & $48.701^{* * *}$ \\
\hline Factor 8 & $.28694^{\mathrm{b}}$ & $-1.22253^{\mathrm{a}}$ & $.39084^{\mathrm{b}}$ & $135.803^{* * *}$ \\
\hline${ }^{* * *} p<.001,{ }^{* *} p<.01$, Means with the same letter are not significantly
\end{tabular}
different by Duncan test $(p<.05, \mathrm{a}<\mathrm{b}<\mathrm{c})$.

각 요인을 구성하는 측정항목에 대한 군집별 분산분석 및 사후검정 결과는 Table 6 에 제시하였다. 군집별 특성을 살 펴보면, 먼저 군집 1 은 발 볼의 엄지관절 부위가 돌출되어 있으면서 엄지 발가락이 바깥쪽으로 휜 형태가 많고, 발목이 굵다는 특징이 있다. 발 앞부분은 발길이에 비해 부피가 큰 데 발등의 높이는 중간 수준이면서 발너비와 발둘레는 큰 편 으로 엄지 발가락이 변형된 발이라 명명하였다. 총 366명 중 119 명, 전체의 3 분의 1 에 해당하는 농업인 $(32.5 \%)$ 이 1 군집에 해당된다. 군집 1 에서 나타나는 발 형태처럼 엄지 발가락이 바깥쪽으로 휘고 엄지관절 부위가 안쪽으로 돌출 하게 되면 일반적으로 통증을 동반하게 되는데, 엄지 발가락 이 휜 정도에 따라 엄지 외반 각도가 $15^{\circ}$ 미만인 경우 정상, $15^{\circ}$ 이상부터 $20^{\circ}$ 미만은 경증 무지외반증 (hallux valgus) 으로, $20^{\circ}$ 이상부터 $40^{\circ}$ 미만은 중등도, $40^{\circ}$ 이상이면 중증 으로 분류한다(Frey, 1991). 이러한 무지외반증은 연령이 높을수록, 그리고 남성보다는 여성에게서 많이 나타나는데 (Scott et al., 2007; Kim, 1996) 본 연구의 대상인 농업인 남성은 동일한 방법으로 측정된 같은 연령대의 일반인 남성 (non-farmers) 보다 엄지 발가락 관절 부위의 돌출이 다수 관찰되어 농작업 특성과 관련이 있을 것으로 추측되며 이에 관해서는 추후 심층적인 분석이 필요할 것으로 사료된다.

무지외반증의 주된 원인을 잘 맞지 않는 신발로 보는 것이 통상적인 견해로, Gorecki(1978), Richards(1991), 
Table 6. The means of foot dimensions by clusters and the result of analysis of variance and Post-hoc test

\begin{tabular}{|c|c|c|c|c|c|c|}
\hline \multicolumn{2}{|c|}{$\begin{array}{ll}\begin{array}{l}\text { Factor } \\
\text { (Foot dimensions) }\end{array} & \text { Cluster } \\
\end{array}$} & \multirow{2}{*}{$\begin{array}{c}1 \\
(\mathrm{n}= \\
119) \\
0.417^{\mathrm{b}}\end{array}$} & \multirow{2}{*}{$\begin{array}{c}2 \\
(\mathrm{n}= \\
81) \\
0.403^{\mathrm{a}}\end{array}$} & \multirow{2}{*}{$\begin{array}{c}3 \\
(\mathrm{n}= \\
166) \\
0.417^{\mathrm{b}}\end{array}$} & \multirow{2}{*}{$\begin{array}{c}\begin{array}{c}\text { Total } \\
(\mathrm{n}=\end{array} \\
366)\end{array}$} & \multirow{2}{*}{\begin{tabular}{|l}
$F$-value \\
$22.508^{* * *}$ \\
\end{tabular}} \\
\hline \multirow{5}{*}{1} & 8.Ball distance & & & & & \\
\hline & 7.Foot width & $0.403^{\mathrm{b}}$ & $0.391^{\mathrm{a}}$ & $0.406^{\mathrm{b}}$ & 0.401 & $19.290^{* * *}$ \\
\hline & 24.Ball circumference & $1.038^{\mathrm{b}}$ & $1.006^{\mathrm{a}}$ & $1.039^{\mathrm{b}}$ & 1.031 & $15.295^{* * *}$ \\
\hline & 25.Instep circumference & $1.038^{\mathrm{b}}$ & $1.016^{\mathrm{a}}$ & $1.038^{\mathrm{b}}$ & 1.033 & $5.717^{* *}$ \\
\hline & $\begin{array}{l}\text { 26.Perpendicular ankle } \\
\text { circumference }\end{array}$ & $1.067^{\mathrm{b}}$ & $1.036^{\mathrm{a}}$ & $1.074^{\mathrm{b}}$ & 1.063 & $16.304^{* * *}$ \\
\hline & 19.Sphyrion height & $0.246^{\mathrm{a}}$ & $0.258^{\mathrm{b}}$ & $0.250^{\mathrm{a}}$ & 0.250 & $11.743^{* * *}$ \\
\hline & $\begin{array}{l}\text { 17.Medial malleolus } \\
\text { height }\end{array}$ & $0.295^{\mathrm{a}}$ & $0.367^{\mathrm{b}}$ & $0.300^{\mathrm{c}}$ & 0.300 & $10.346^{* * *}$ \\
\hline & $\begin{array}{l}\text { 22. Height of upper } \\
\text { point of heel point }\end{array}$ & $0.190^{\mathrm{a}}$ & $0.195^{\mathrm{b}}$ & $0.192^{\mathrm{a}}$ & 0.192 & 2.686 \\
\hline & 15.Ankle height & $0.302^{\mathrm{a}}$ & $0.311^{b}$ & $0.315^{\mathrm{b}}$ & 0.310 & $16.578^{* * *}$ \\
\hline & $\begin{array}{l}\text { 16.Lateral malleolus } \\
\text { height }\end{array}$ & 0.275 & 0.278 & 0.278 & 0.277 & 1.119 \\
\hline \multirow{4}{*}{3} & 40.Center line angle & $0.750^{\mathrm{a}}$ & $2.140^{\mathrm{b}}$ & $2.380^{\mathrm{b}}$ & 1.800 & $70.172^{* * *}$ \\
\hline & 35.Medial ball width & $0.193^{b}$ & $0.173^{\mathrm{a}}$ & $0.176^{\mathrm{a}}$ & 0.181 & $53.656^{* * *}$ \\
\hline & 37.Toe 1 angle & $11.920^{\mathrm{c}}$ & $9.175^{b}$ & $6.422^{\mathrm{a}}$ & 8.819 & $35.314^{* * *}$ \\
\hline & 36.Lateral ball width & $0.210^{\mathrm{a}}$ & $0.218^{\mathrm{b}}$ & $0.229^{\mathrm{c}}$ & 0.220 & $57.192^{* * *}$ \\
\hline \multirow{3}{*}{4} & 31.Heel to tibiale length & $0.740^{\mathrm{b}}$ & $0.730^{\mathrm{a}}$ & $0.733^{\mathrm{a}}$ & 0.735 & $13.156^{* * *}$ \\
\hline & $\begin{array}{c}\text { 34. Ball center to } \\
\text { heel length }\end{array}$ & 0.693 & 0.695 & 0.697 & 0.695 & 2.238 \\
\hline & $\begin{array}{c}\text { 33. Ball center to } \\
\text { toe } 2 \text { length }\end{array}$ & $0.288^{\mathrm{a}}$ & $0.301^{\mathrm{b}}$ & $0.288^{\mathrm{a}}$ & 0.291 & $22.151^{* * *}$ \\
\hline \multirow{3}{*}{5} & 4.Heel to instep length & $0.542^{\mathrm{a}}$ & $0.541^{\mathrm{a}}$ & $0.564^{\mathrm{b}}$ & 0.552 & $14.237^{* * *}$ \\
\hline & $\begin{array}{l}\text { 27. Heel to instep } \\
\text { circumference }\end{array}$ & $1.434^{\mathrm{a}}$ & $1.420^{\mathrm{a}}$ & $1.469^{\mathrm{b}}$ & 1.447 & $15.247^{* * *}$ \\
\hline & 14.Instep Height & $0.257^{\mathrm{ab}}$ & $0.258^{\mathrm{b}}$ & $0.251^{\mathrm{a}}$ & 0.256 & $3.346^{*}$ \\
\hline \multirow{3}{*}{6} & 39. Ball line angle & $14.900^{\mathrm{b}}$ & $13.090^{\mathrm{a}}$ & $13.200^{\mathrm{a}}$ & 13.730 & $13.585^{* * *}$ \\
\hline & $\begin{array}{l}\text { 32.Heel to fibulare } \\
\text { length }\end{array}$ & 0.642 & 0.647 & 0.646 & 0.645 & 2.713 \\
\hline & 3. Heel to toe 5 length & $0.828^{\mathrm{a}}$ & $0.833^{\mathrm{b}}$ & $0.834^{\mathrm{b}}$ & 0.832 & $4.805^{* *}$ \\
\hline \multirow{3}{*}{7} & 6.Ankle Thickness & $0.415^{\mathrm{b}}$ & $0.405^{\mathrm{a}}$ & $0.404^{\mathrm{a}}$ & 0.408 & $20.221^{* * *}$ \\
\hline & 5.Heel to ankle length & $0.462^{\mathrm{b}}$ & $0.448^{\mathrm{a}}$ & $0.450^{\mathrm{a}}$ & 0.454 & $33.561^{* * *}$ \\
\hline & $\begin{array}{l}\text { 29. Horizontal ankle } \\
\text { ircumference }\end{array}$ & $1.128^{\mathrm{c}}$ & $1.108^{\mathrm{b}}$ & $1.080^{\mathrm{a}}$ & 1.102 & $21.465^{* * *}$ \\
\hline 8 & 2. Heel to toe 1 length & $1.000^{\mathrm{b}}$ & $0.989^{\mathrm{a}}$ & $1.000^{\mathrm{ab}}$ & 0.997 & $127.063^{* * *}$ \\
\hline
\end{tabular}

${ }^{* * *} p<.001,{ }^{* *} p<.01,{ }^{*} p<.05$.

- Means with the same letter are not significantly different by Duncan test $(p<.05, \mathrm{a}<\mathrm{b}<\mathrm{c})$

- All foot dimensions are indexical values divided by the foot length except foot angle dimensions

Coughlin and Thompson(1995), Frey(2000), Coughlin and Jones (2007) 등 여러 연구자들이 잘 맞지 않는 신발과 무지외반증 간에 높은 관련성이 있음을 보고한 바 있다. 또한
Hoffmann(1905), James (1939), Sim-Fook and Hodgson (1958) 등의 연구에서는 신발을 신는 민족에 비해 신발을 신지 않는 민족에게서는 이와 같은 발의 변형이 거의 나타나 지 않았던 것을 신발과 무지외반증의 관련성을 추정할 수 있는 간접적인 근거로 제시하였다. 그러나 Kilmartin and Wallace(1993), Menz and Morris(2005) 등은 잘 맞지 않 는 신발을 착용한 사람들 중 무지외반의 비율이 높은 것은 사실이나 발의 아치높이, 근육의 불균형, 제 1 중족골의 형태 나 위치 등 여러 요인들이 복합적으로 무지외반증을 야기할 수 있다고 하였다. 즉 잘 맞지 않는 신발은 무지외반증을 야 기할 수 있는 여러 가지 요인 중 하나이거나 무지외반증으로 인해 발생할 수 있는 문제점 중 하나일 뿐 근본적 원인은 아 닌 것으로 생각된다. 오히려 이러한 무지외반증은 유전적 · 인종적 특징 및 신체 특성, 직업이나 습관, 건강상태(Dunn et al., 2003; Won and Lee, 2010, Lee et al., 2011) 등 광 범위한 요인들의 영향을 일생에 거쳐 받게 되는데, 우리나라 농업인의 경우 장시간 쪼그려 앉거나 구부린 자세에서의 반 복된 저상작업(底床作業)이 많은 것(Song et al., 2010)이 발을 변형시키는 요인 중 하나인 것으로 사료된다.

군집 2는 발 앞부분이 발등은 높지만 발너비가 작아 편평 률이 크고 둥근 발로 발둘레와 볼거리가 모두 작아 가는 형 태이며, 발볼 각도도 작고 발목도 가늘며 변형이 없어 일반 발이라 하였다. 이들 중에는 둘째 발가락이 상대적으로 긴 형태가 많았는데 군집 2의 약 $70 \%$ 정도의 인원이 둘째 발 가락이 엄지 발가락 보다 긴 그리스인 형 (Greek Foot)에 해당되었다. 전체 중 81 명 $(22 \%)$ 만이 군집 2에 속해 3개의 군집 중 인원이 가장 적었다. 우리나라 농촌지역 성인을 대 상으로 한 $\mathrm{Kim}(1996)$ 의 연구에서는 정돈된 형 (Squared foot)이 $68.6 \%$ 로 가장 많게, 그리스인 형은 $11.8 \%$ 로 가장 적게 나타났고, 발가락 유형과 무지외반증 출현의 관련성을 분석한 결과 그리스인 형에서 무지외반증이 가장 적었고, 정 돈된 형, 이집트인 형 순으로 많은 것으로 나타났다. 이러한 경향은 본 연구에서 발이 가늘고 변형이 적은 일반발인 군집 2에서 그리스인 형의 발이 많았던 것과 일치하는 것으로 보 인다. 한편, Viladot(1973)의 스페인 사람을 대상으로 한 연 구 결과에서는 이집트인 형 (Egyptian foot)이 69\%로 가장 많았다.

군집 3은 발 앞부분이 발너비, 볼거리, 발둘레 등이 크게 나타나 부피는 크지만 발등은 낮아 편평률이 작은 넙적하게 퍼진 형태의 발이다. 엄지는 곧으나 발 볼이 바깥쪽으로 돌 출된 발목이 가는 발로 발꿈치 발등의 길이가 긴 특징이 있으며, 넙적한 발이라 하였다. 군집 3 에 속하는 인원은 166 명 $(45 \%)$ 으로 본 연구에 참여한 남성 농업인들 중에서 가장 많은 인원이 군집 3 에 해당된다. 군집 3 과 같이 발 앞 부분이 넓고 편평해서 넙적한 형태는 노인 발에서 나타나는 
대표적 특징 중 하나로 알려져 있는데, 도시 거주자를 대상 으로 한 다수의 선행연구들에서 젊은 성인의 경우 변형이 없고 좁은 일반발 형이 대부분 이었던 반면 60세 이상 노인 의 경우는 왜소한 발과 넙적한 발이 차지하는 비율이 젊은층 에 비해 상대적으로 높은 경향을 보였다. 사이즈코리아 측정 자료를 이용하여 60대 남성의 발 형태를 분석한 Seok and $\operatorname{Park}$ (2007)의 연구에서는 넙적한 발이 전체 중 $22 \%$, 가는 발이 $49.3 \%$ 를 차지하여 일반발이 대부분인 젊은 연령층과 차이가 있다고 하였고, 60세 이상과 30세 미만 성인 여성의 발을 비교한 Park(2005)의 연구에서도 젊은 연령층에서는 일반발이 $71.3 \%$, 넓은 발이 $17.7 \%$ 였지만 노인층에서는 일 반발이 $22.7 \%$, 넓은 발이 $49.2 \%$ 로 확연한 차이를 보인 바 있으며, Chun and Choi(2000), Seong (1999) 등의 연구에 서도 유사한 경향을 나타내어 넙적한 형태의 발이 노인층에 서 나타나는 특성으로 분류되었다. 그러나 본 연구에 참여한 농업인은 40 70대의 넓은 연령층을 포함하고 있음에도 노 인발의 특징을 나타내고 있는 군집 3에 $45 \%$ 나 속해 있어 일반인(non-farmers) 과는 차이가 있다고 할 수 있는데, 이 러한 차이는 연령대별 군집의 분포(Table 7)를 살펴보면 보 다 확실하게 알 수 있다. 낮은 연령층인 40 대와 50 대 중 넙 적한 발인 군집 3 에 해당되는 농업인이 각각 $50 \%$ 와 $53.3 \%$ 로 이 연령층의 절반 이상이나 되었고, 60 대는 $38.6 \%, 70$ 대 는 $44.8 \%$ 로 오히려 적어진 경향을 보이지만 그래도 세 군 집 중 가장 많은 인원이 군집 3 에 속해 있어 넙적한 발이 농 업인 발의 대표적인 특성이라 할 수 있을 것이다. 특히 이러 한 결과는 도시 거주 성인을 대상으로 한 상기 선행연구들 (Seok and Park, 2007; Park, 2005; Park and Nam, 2005; Chun and Choi; 2000; Seong, 1999)에서 60세 미만의 도 시 거주 성인은 대부분이 변형이 없는 일반발이 가장 많았 고 넙적한 발에 해당하는 사람은 연령이 높아지면서 점차 많아지긴 하지만 그 비율이 농업인에 비해 그다지 높지 않 았던 것과 큰 대조를 이룬다. 한편, 일본 북 큐슈 지방 농업 인과 도시 거주자의 발길이와 발너비를 측정한 Hojo and

Table 7. The age profile of clusters

\begin{tabular}{c|c|c|c|c|c}
\hline \multirow{2}{*}{ Cluster } & \multicolumn{5}{|c}{ Age group } \\
\cline { 2 - 6 } & $40 \sim 49$ & $50 \sim 59$ & $60 \sim 69$ & $70 \sim 79$ & Total \\
\hline \multirow{2}{*}{1} & 17 & 26 & 39 & 37 & 119 \\
& $(38.6 \%)$ & $(28.9 \%)$ & $(30.7 \%)$ & $(35.2 \%)$ & $(32.5 \%)$ \\
\hline \multirow{2}{*}{2} & 5 & 16 & 39 & 21 & 81 \\
& $(11.4 \%)$ & $(17.8 \%)$ & $(30.7 \%)$ & $(20.0 \%)$ & $(22.1 \%)$ \\
\hline \multirow{2}{*}{3} & 22 & 48 & 49 & 47 & 166 \\
& $(50.0 \%)$ & $(53.3 \%)$ & $(38.6 \%)$ & $(44.8 \%)$ & $(45.4 \%)$ \\
\hline \multirow{2}{*}{ Total } & 44 & 90 & 127 & 105 & 366 \\
& $(100.0 \%)$ & $(100.0 \%)$ & $(100.0 \%)$ & $(100.0 \%)$ & $(100.0 \%)$ \\
\hline
\end{tabular}

Nakashima(1985)의 연구에서는 농업인의 발이 도시 거주 학생보다 넙적하였고 연구자들은 이러한 차이가 그들의 생 활의 차이에 기인한다고 하여 본 연구와 일치하는 경향을 보였다.

한편 Castro et al.(2010)은 60세 이상 브라질인을 대상 으로 조사한 결과 발 볼 둘레, 발등 둘레 등 발 앞부분의 부피가 큰 경우 발에 통증을 느끼는 사람이 많았다고 하였는 데, 이러한 사실로부터 발너비와 볼너비, 발둘레가 일반인보 다 큰 농업인은 발에서 느끼는 통증이나 불편감이 클 것으로 예측된다. 실제 Lee and Choi(1996)의 연구 결과에서도 다 수의 농업인 $(84 \%)$ 이 착용하고 있는 신발에 대한 불편감을 호소하였고, 그 중 발등이 조인다거나 볼이 좁다는 맞음새에 관한 불편사항이 많았다고 조사된 바 있다.

아래에는 각 군집별 발 형상 특징을 가시적으로 나타내 기 위해 본 연구에 참여한 남성 농업인 중 각 군집별로 한 명씩 추출하여 위에서 본 발의 3차원 형상을 제시하였다 (Figure 3).

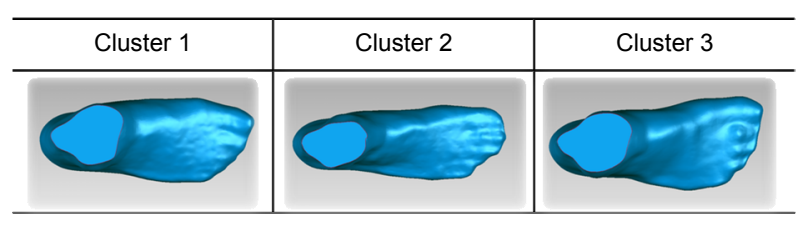

Figure 2. 3D Foot scan image by clusters

\section{Conclusion}

본 연구는 한국 농업인의 발 유형에 적합한 인간공학적 농 작업화 설계를 위한 기초자료를 제공하기 위해 수행되었다. 이를 위해 전국 8 개 도의 16 개 농촌마을에서 40 세 이상 80세 미만인 농업인의 발을 3 차원 발스캐너를 이용하여 측 정하였으며, 본 보에서는 전체 수집한 자료 중 남성 농업인 366 명의 발 형태를 분석하여 다음과 같은 결과를 얻었다.

남성 농업인 발 측정치에 대한 최종 요인분석 결과 8 개의 요인이 추출되었고, 총 $82.5 \%$ 의 설명력을 나타냈다. 요인 1 은 볼거리, 발둘레 등 발 앞쪽 부위의 형태를 나타내는 요인 이며, 요인 2는 복사 높이와 관련된 요인, 요인 3 은 볼 내측 의 형태 및 엄지의 변형 정도와 관련이 있었다. 요인 4 는 발 중심점상측길이와 발중심점하측길이의 비율과 관련이 있었 으며, 요인 5는 발꿈치 발등 사이의 형태를 나타내며, 요인 6은 볼 가측의 형태 및 새끼 발가락의 위치와 관련된 요인, 요인 7 은 발목의 굵기와 관련된 요인이었다. 마지막으로 요 
인 8은 엄지 발가락과 둘째 발가락의 상대적 길이 차이와 관련된 요인으로 분석되었다.

8 개의 요인점수를 독립변수로 하여 군집분석을 실시한 결 과 3 개 유형으로 분류되었다. 군집 1 은 엄지 발가락이 변형 된 발로 남성 농업인 중 $32.5 \%$ 가 이에 해당되었다. 발 볼의 엄지관절 부위가 돌출되어 있으면서 엄지 발가락이 바깥쪽 으로 휜 형태가 많고, 발목이 굵다는 특징이 있다. 군집 2는 발 앞부분이 발등은 높으면서 발너비가 작아 편평률이 크고 단면이 둥근 발로 발둘레와 볼거리도 모두 작아 가는 형태이 며, 발 볼 각도도 작고 발목도 가늘며 변형이 없는 일반발로 $22 \%$ 만이 군집 2에 속해 3 개의 군집 중 인원이 가장 적었 다. 이들 중에는 둘째 발가락이 상대적으로 긴 그리스인 형 (Greek Foot)이 많았다. 군집 3은 발너비, 볼거리, 발둘레 등 발 앞부분의 부피는 크지만 발등은 낮은 편평률이 작은 넙적하게 퍼진 형태의 발로 $45 \%$ 가 이에 속해 군집들 중 인 원이 가장 많았다. 이와 같이 발 앞부분이 넓고 편평하면서 넙적한 형태는 노인 발에서 나타나는 대표적인 특징 중 하나 로 알려져 있다.

남성 농업인 발유형의 분포를 연령층별로 살펴보면, 40 대 와 50 대 중 넙적한 노인발의 특징을 보이는 군집 3 에 속한 농업인이 각각 $50 \%$ 와 $53.3 \%$ 로 이 연령층의 절반 이상이나 되었고, 60 대는 $38.6 \%, 70$ 대는 $44.8 \%$ 로 40 50대에 비해 오히려 적어진 경향을 보이지만 그래도 세 군집 모두 가장 많은 인원이 군집 3 에 속해 있어 넙적한 발을 농업인 발의 일반적인 형태라 할 수 있을 것이다. 이러한 결과는 도시 거 주자를 대상으로 한 다수의 선행연구에서 40 50대의 성인 의 경우 변형이 없고 좁은 일반발 형이 대부분이었던 것과 매우 대조적이다. 또한 60세 이상 도시 노인의 경우 넙적한 발이 차지하는 비율이 젊은층에 비해 상대적으로 높은 경향 을 보였던 것과도 차이가 있었다.

이상에서 농업인의 발 유형 및 형태가 일반인과 차이가 있음을 확인할 수 있었다. 이러한 차이로 인해 획일적인 형 태로 제작되고 있는 작업화를 착용하는 농업인들은 신발 맞 음새에 대한 불편감을 느낄 수 있으며, 이러한 불편감은 또 다시 발의 변형을 야기하는 원인 중 하나가 될 수 있다. 따 라서 농작업화 설계 시에 농업인의 발 형태에 관한 이해가 선행되어야 할 것으로 사료되며, 본 연구의 결과는 편안한 농작업화 개발을 위한 기초자료로 활용될 수 있을 것으로 기대된다. 본 연구의 결과는 지수치를 활용하여 발의 형태를 분석한 것으로 추후 현행 치수체계에서 농업인과 일반인의 실측 치수 및 그 분포에 대한 비교 분석이 필요할 것이다.

\section{Acknowledgements}

This study was supported by 2012 Postdoctoral Fellowship Program of National Academy of Agricultural Science (Project No. PJ0084202012, Project leader: Dohee Kim), Rural Development Administration, Republic of Korea.

\section{References}

Ashizawa, K., Kumakura, C., Kusumoto, A. and Narasaki, S., Relative foot size and shape to general body size in Japanese, Filipinas and apanese with special reference to habitual footwear types, Annals of Human Biology, 24(2), 117-129, 1997.

Burns, S., Leese, G. and Mcmurdo, M., Older people and ill fitting shoes. Postgraduate Medical Journal, 78(920), 344-346, 2002.

Castro, A. P, Rebelatto, J. R. and Aurichio, T. R., The relationship between foot pain, anthropometric variables and footwear among older people, Applied Ergonomics, 41, 93-97, 2010.

Chun, J. S. and Choi, S, H., A Study on Purchase and Use of Women's Dress Shoes, Journal of the Korean Society of Clothing and Textiles, 24(2), 2000

Coughlin, M. J. and Thompson, F. M., The high price of high-fashion footwear. Instr Course Lect, 44, 371-377, 1995.

Coughlin, M. J. and Jones, C. P., Hallux valgus:demographics, etiology, and radiographic assessment, Foot \& Ankle International, 28(7), 759 $-777,2007$.

Dunn, J. E., Link, C. L., Felson, D. T., Crincoli, M. G. Keysor, J. J. and McKinlay, J. B., Prevalence of Foot and Ankle Conditions in a Multiethnic Community Sample of Older Adults, American Journal of Epidemiology, 159(5), 491-498, 2003.

Frey, C., Osteoarthritis and static deformity of the forefoot, In G. J. Sammarco, $1^{\text {st }}$ Ed., Foot an ankle manual, Philadelphia, PA: Lea \& Febiger, 136-144, 1991.

Frey, C., Thompson, F., Smith, J., Sanders, M. and Horstman, H., American Orthopaedic Foot and Ankle Society women's shoe survey, Foot \& Ankle, 14(2), 78-81, 1993.

Frey, C., Foot health and shoewear for women, Clin Orthop, 372(March), 32-44, 2000

Gorecki, G. A., Shoe related foot problems and public health, J Am Podiatry Assoc, 4, 245-247, 1978.

Han, H. J., Study of Shoes Size suitability for Korean Women, Unpublished master's thesis, University of Ulsan, 2005.

Hoffmann, P., Conclusions drawn from a comparative study of the feet of barefooted and shoe-wearing peoples, Am J Orthop Surg, 3, 105-136, 1905.

Hojo, T. and Nakashima, T., The foot shape of school girls and female farm workers in northern Kyushu, Journal of University of Occupational 
and Environmental Health, 7(3), 265-268, 1985.

ISO, ISO 9407: Shoes sizes-Mondopoint system of sizing and marking Shoes sizes-Mon-dopoint system of sizing and marking, Genova: International Organization for Standardization, 2001.

James, C. S., Foot prints and feet of natives of the Solomon Islands. Lancet, 234, 1390-1393, 1939

Japanese Standards Association, JIS S 5037: Sizing system for shoes Sizing system for shoes, Tokyo: Japanese Standards Association, 1998.

Jung, S. K. and Lee, S. D., A study on Anthropometric measurement and Type classification of Foot for the Elderly, Journal of korean society of design science, 14(2), 95-105, 2001.

KATS, KS G 3405, Lasts for shoes, Gwacheon: Korean Agency for Technology and Standards, 2001.

KATS, KS M 6681, Sizing system for foot wear, Gwacheon: Korean Agency for Technology and Standards, 2007.

KATS, Report of the $5^{\text {th }}$ anthropometry of Size Korea. Gwacheon: Korean Agency for Technology and Standards, 2004.

Kilmartin, T. E. and Wallace, W. A., The aetiology of hallux valgus: A critical review of the literature, Foot, 3, 157-167, 1993.

Kim, D. H., Hwang, K.S., Lee, K. S., Kwon, J. Y., Lee, H. H., Min, K. D., Kim, S. C. and Shin, Y. S., Korean Farmers' Anthropometric Characteristics of Foot Shape, Proceedings $47^{\text {th }}$ The Korean Society of Occupational and Environmental Medicine, 424-426, 2011.

Kim, D. H., Lee, K. S. and Kim, H. C., Anthropometric Characteristics of Korean Farmers in a Sitting Posture. The Korean Journal of Community Living Science, 22(1), 63-76, 2011.

Kim, T. K., A Study of Foot Types and Deformities of Adults in Rural Community in Korea. Unpublished Master's thesis, Hanyang University, Seoul, 1996.

Kouchi, M. and Mochimaru, M., The Feet of Runners: Do They Differ from the Non-Runners' Feet? Proceedins $6^{\text {th }}$ Footwear Biomechanics Symposium-Queenstown 2003, 2003.

Kouchi, M., Foot dimensions and foot shape: Differences due to growth, generation and ethnic origin. Anthropol Sci, 106(suppl), 161-188, 1998.

Lee, E. L. and Choi, J. Y., The Effect of the Functional Insole during Stair Climbing of Elderly Women. Journal of Sport and Leisure Studies, 46(1), 921-930, 2011.

Lee, J. H., Kim, S. B., Lee, K. W. and Han, D. W, Biomechanical Factors Associated with Plantar Fasciitis in Non-obese Patients, The Korean Journal of Sports Medicine, 29(1), 9-14, 2011.

Lee, K. S. and Choi, J. W., A study of Agricultural fatigue shoes - A comparative study of heat load by shoe type, The Korean Journal of Community Living Science, 7(2), 99-108, 1996.

Leem, Y. M., Bang, H. K. and Shin, K. J., Foot Classification for Manufacturing of Comfortable Shoes, Journal of the Korea Society of Safety, 22(6), 81-86, 2007.

Menz, H. B. and Morris, M. E., Footwear characteristics and foot problems in older people. Gerontology, 51(5), 346-351, 2005.

Moon, M. O., Cluster Analysis for Foot Type (I), Journal of the Korean Society of Clothing and Textiles, 18(2), 211-220, 1994.

Morimoto, M. and Okada, M., Somatometrical features of the foot in male athletes, Jpn J Hum Posture, 5(2), 101-105(In Japanese), 1985.
Park, J. K. and Nam, Y. J., Classification of Sole Types of Elderly Women by Scanning Method, Journal of the Korean Society of Clothing and Textiles, 29(5), 595-606, 2005.

Park, J. K., Classification of Foot Types for Shoes Size System of Elderly Women, Journal of the Korean Society of Clothing and Textiles, 55(2), 33-44, 2005

Richards, R. N., Calluses, corns and shoes. Semin Dermatol, 10, 112-114, 1991.

Scott, G., Menz, H. B. and Newcombe, L., Age-related differences in foot structure and function, Gait \& Posture, 26, 68-75, 2007.

Seong, D. H., Jung, E. S. and Cho, Y. J., A Study on the Categorization of Korean Foot Shapes, Journal of the Ergonomics Society of Korea, 25(2), 107-118, 2006

Seok, H. J. and Park, J. E., The Classification of Elderly Men's Feet, The Journal of the Korean society of costumes, 57(10), 50-59, 2007.

Seong, W. K., The Classification of Foot type and the Analysis of Foot Shape for Older Adult Women, Journal of the Korean Society of Clothing and Textiles, 23(1), 99-110, 1999

Sim-Fook, L. and Hodgson, A. R., A comparison of foot forms among the non-shoe and shoe-wearing Chinese population. J Bone Joint Surg Am, 40-A, 1058-1062, 1958.

Song, B. K., Nature Therapeutics. Dae-gu: Tong Yang Communication Education, 1986.

Song, H. S., Yoo, S. K. Choi, C. K. Lee, C. G. and Lee, K. S. Radiological Flattening of Lumbar Lordosis and Related Factors in Some Korean Farmers, Korean J Occup Environ Med, 22(4), 279-289, 2010.

Sparger, C., Anatomy and Ballet: A Handbook for Teachers of Ballet. London: Black., 1970.

Statistics Korea., Report on the Agricultural Survey. Daejeon: Statistics Korea., 2010.

Viladot, A., Metatarsalgia due to biomechanical alterations of the forefoot, Orthop. Clin. Of North Am., 4(1), 314-319, 1973.

Won, K. H. and Lee, M. G., Effects of a strength exercise training for foot intrinsic muscle on height of medial Longitudinal arch and balance in females aged 20's, Exercise Science, 19(4), 351-360, 2010.

Wunderich, R. E. and Cavanagh, P. R., Gender differences in adult foot shape: implications for shoe design, Medicine \& Science in Sports \& Exercise, 33(4), 605-611, 2001

\section{Author listings}

Dohee Kim: dohi2@snu.ac.kr

Highest degree: $\mathrm{PhD}$, Dept of Clothing \& Textile, Seoul National University

Position title: Postdoctoral Researcher, Dept of Agricultural Engineering, National Academy of Agricultural Science, RDA

Areas of interest: Clothing Ergonomics, Anthropometric information, Occupational Safety \& Health, PPE, WMSDs 
Kyoung Suk Hwang: ksjamong@naver.com

Highest degree: $\mathrm{PhD}$, Dept of Clothing \& Textile, Seoul National

University

Position title: Patent Examiner, Textile and Consumer Goods Examination

Division, Korean Intellectual Property Office

Areas of interest: Clothing Ergonomics, Anthropometric information, PPE

Kyung Suk Lee: leeks81@korea.kr

Highest degree: $\mathrm{PhD}$, Dept of Clothing \& Textile, Seoul National

University

Position title: Senior Researcher, Dept of Agricultural Engineering,

National Academy of Agricultural Science, RDA

Areas of interest: Agriculture, Agricultural Safety \& Health
Date Received : 2012-10-12

Date Revised :2012-11-19

Date Accepted : 2012-11-21 